\title{
Changing FDR's image
}

\author{
Michael C Caldwell, Kathleen A Titsworth
}

The town of Hyde Park, New York is the birthplace of Franklin Delano Roosevelt and currently houses the Presidential library and museum in honour of the 32nd President of the United States. In an effort to honour the past President and to stimulate tourism, there has recently been discussion about changing the official town seal, a combination of the family crests of two founding families of Hyde Park, the Roosevelts and the Stoutenbourghs. The ornate design includes roses topped with the head and neck of two geese facing one another (figure 1).

There is now a proposal that a silhouette of Franklin Delano Roosevelt replace the official town seal. This has already been adopted by many departments within Hyde Park over the past several years, and the silhouette adorns the Chamber of Commerce signs welcoming people into Hyde Park. Recently, however, controversy about the Roosevelt silhouette has gained national, and even international, attention.

The proposed seal is a silhouette of Roosevelt with his well known cigarette and cigarette holder (figure 2)-the very thing that contributed to his early demise at the age of 63 (see below). Does the use of such an image perpetuate the social acceptability of smoking and even promote cigarette use? Would Hyde Park's endorsement of the image as its official town seal offer the perception that the town officially endorses cigarettes?

According to the Hyde Park chamber of commerce, the FDR silhouette was created by a local artist and has been welcoming people to the town since the 1960s. Over time it has grown in popularity and is currently used unofficially throughout the town. The silhouette can be found at the chamber of commerce office; on the stationery of the chamber, the town board, and the town legal department; and on Roosevelt Fire Company trucks and highway department trucks. A similar figure can be found on the sculpture at the town high school, the nickname of which is "the Presidents".

In response to the popularity of the FDR silhouette, a town councilman, Kevin Bergin, proposed in June 1995 to adopt this silhouette as the official town seal to commemorate the fiftieth anniversary of Roosevelt's death and the end of World War II. This proposal was supported by many but has also met with opposition, the strongest coming from public health officials.

The cause of death of Franklin Delano Roosevelt in 1945 was a massive cerebral haemorrhage. In addition the President wase known to have severe hypertension, chronicbronchitis, and left ventricular failure. ${ }^{1}$ All the: ailments that plagued the President are consid $-\vec{\omega}$ ered to be tobacco-related diseases. In his finalo years, as his health grew poorer, FDR's physicians made several requests for him tof stop smoking. Despite this, however, Roosevelt continued smoking until his death.

In effect, the silhouette of Franklin? Roosevelt with a cigarette is actually showing $\vec{\sigma}$ the President engaging in the very behaviouro that contributed to his death. Is this the proper way to formally honour the past President ando does it neglect to take into account the ${ }^{\stackrel{D}{~}}$ detrimental effect that cigarette smoking hadi on FDR's life? The debate is not whethero Roosevelt was a well known smoker butס whether that image is the one that should bes remembered and perhaps emulated by futureo generations. At the heart of the issue is theo question of whether great American presidents $\$$ should be commemorated by the very thing $\overrightarrow{\vec{O}}$ that caused their demise. Would a picture be 3 chosen of John Kennedy or Abraham Lincoln? with an assassin's bullet to honour them?

A similar controversy has been played outo recently at the United States postal service. $A_{\stackrel{O}{O}}^{\circ}$ stamp commemorating "blues" guitaristô Robert Johnson was designed without the ciga-o rette that appeared in the photograph from? which the stamp was based. The Citizens $\underline{\partial}$ Stamp Advisory Committee recommended deleting the cigarette from the stamp so as not. to appear to be promoting cigarettes..$^{2} \mathrm{O}$ Smokers' rights organisations protested, and accused the postal service of censorship.

This is not the only instance where smokers $\frac{D}{2}$ are seen without their cigarettes on postage stamps. Smokers Edward R Murrow, trade o union boss George Meany, and Nat King Colen were all represented on stamps that did nots show them with their trademark cigarettes, ${ }_{0}$ which also contributed to their early deaths. ${ }^{2}{ }_{0}^{2}$

Others have taken active roles in promoting a healthier, non-smoking image. Playskool, $a \stackrel{\Phi}{+}$ division of the Hasbro Toy Group, the maker 0 of "Mr Potato Head", took the toy's pipe away웅 in the 1980s (Consumer Information Line, $\stackrel{\mathbb{D}}{?}$ November 1995).

The Pep Boys, a United States national auto parts store with more than 470 locations in 330 states, decided to promote a healthier image for their workforce by removing the cigar that had been part of their logo for many years. "Manny", "Moe", and "Jack", three caricatures of the original owners, had adorned the logo since the company was founded in 1921 . 


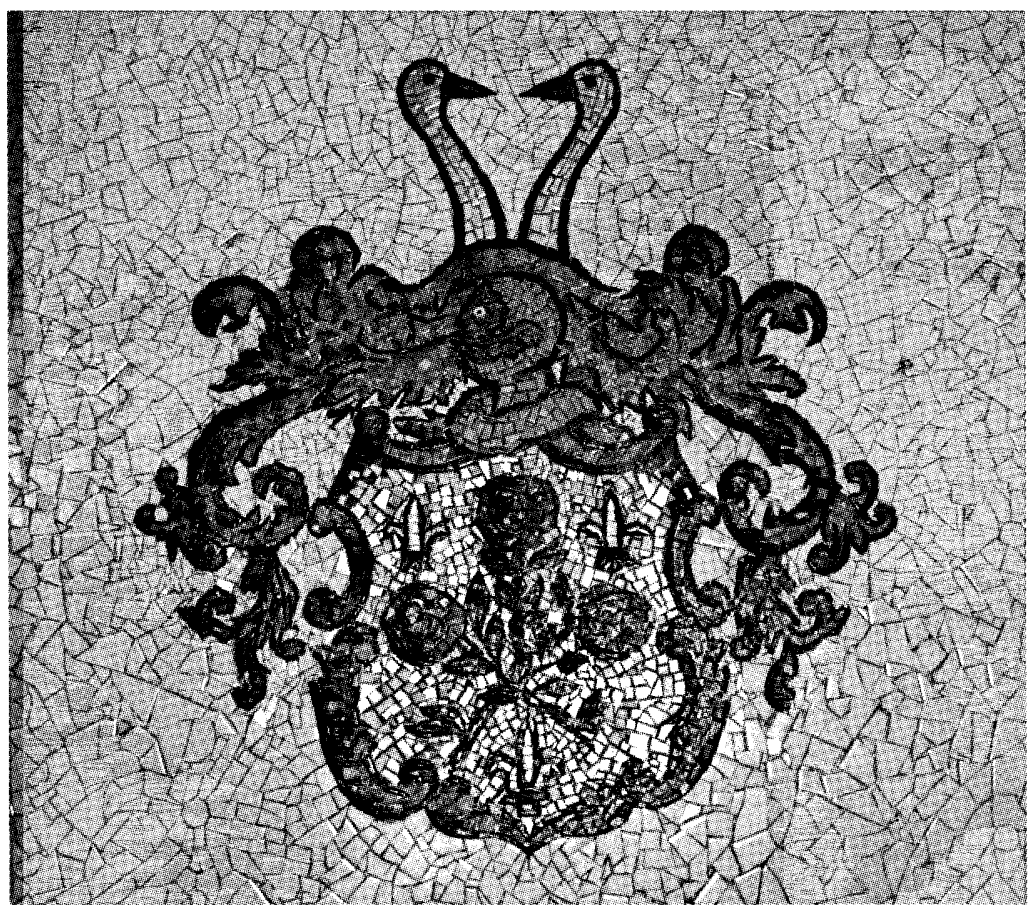

Figure 1 Current town seal for the town of Hyde Park, in a tile mosaic.

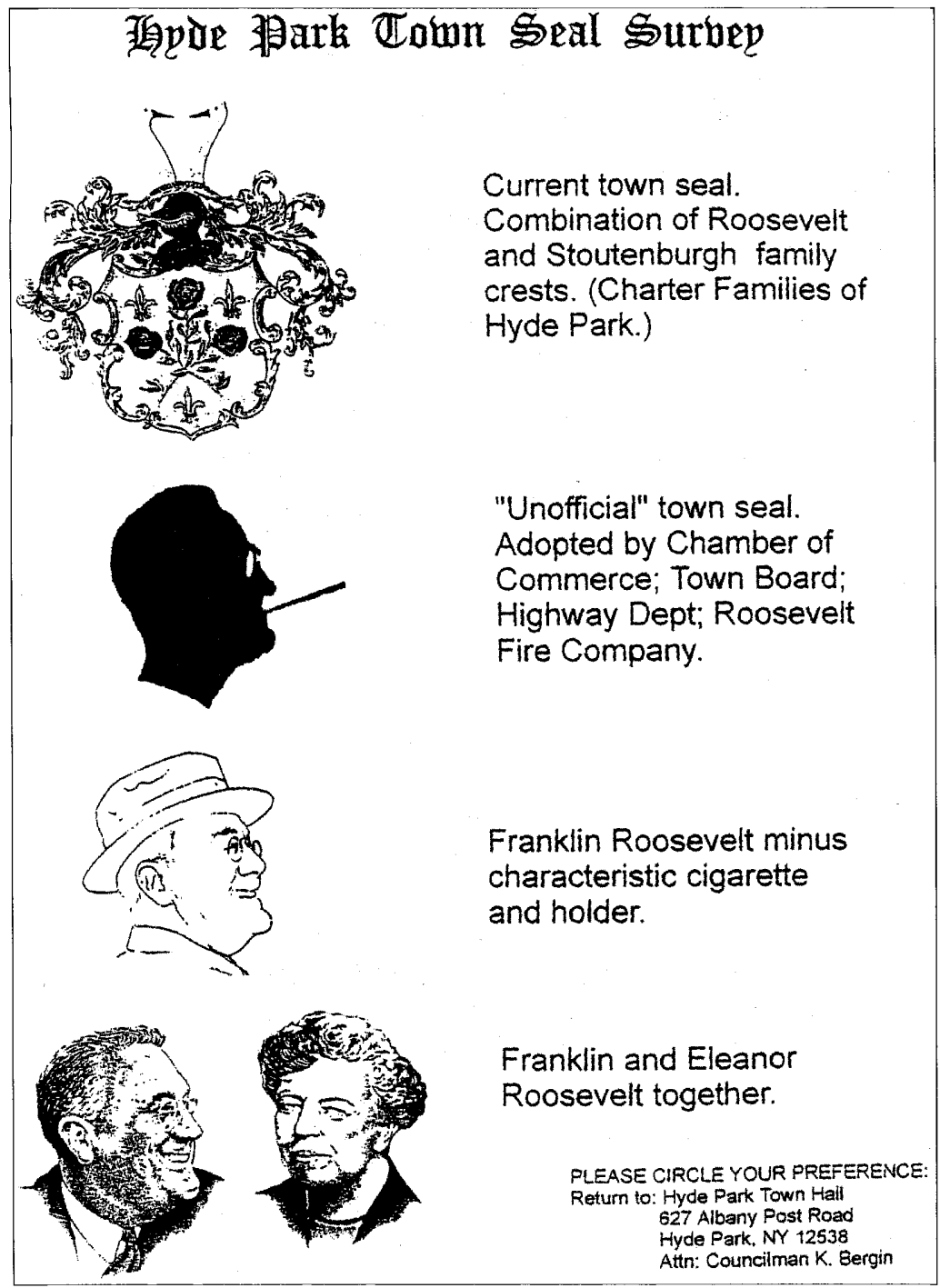

Figure 2 A questionnaire used in an informal survey distributed by councilman Kevin Bergin to Hyde Park residents, asking their preference for an official town seal.

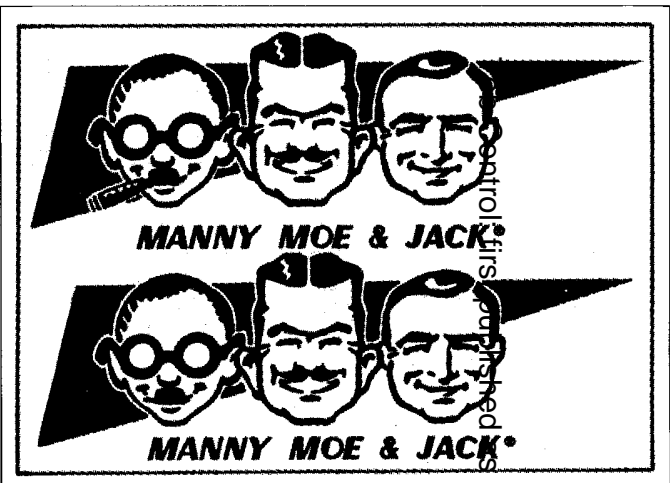

Figure 3 Old logo (top, with cigar) and 유 ov logo (bottom, without cigar) for the Pep Boys, a US national auto parts store with more than 470 locations in 33 st

The "Manny" character could be fofound smoking a cigar until the Great American Smoke-Out in 1990. On that day, the company removed the cigar from Mangyy's mouth. Statues at each store were altered, and the company stationery and literature were replaced with the new smokeles\$l logo (figure 3). A conversation with the $\frac{\Phi}{J}$ director of corporate communications, B Tit $_{\text {H }}$ Furtkevic (August 1995), revealed that, despite the fact that Manny's cigar was a well kngwn symbol, the company felt it was an unheaphy one and, after 69 years, opted to promote a healthier image.

通lth officials,

As well as upsetting public he्gllth officials, Roosevelt might have upset the P\&esident himself. There is evidence that Frankfin Roosevelt was aware of the ill effects of smoking and the dislike of smoking by others. In a editorial he wrote for the Harvard Crimson on 16 October 1903, he outlined the problem of smoking at football games. His article requested a separate section for ladies "without fear of being asphyxiated" and for other ticketoholders who object to smoking. This editorial, written more than 60 years before the 1964 repert of the US Surgeon General that outlined the about cigarette smoking, ${ }^{3}$ forces one to question whether FDR was aware of the possible ill effects that his behaviour may have had on himself and others.

Councilman Kevin Bergin rela a story he encountered while researchin the late President's life (September 1995\% Bergin said that Roosevelt, who smoked Gamels, was apparently offered a large amountiof money to act as a spokesman for that particullar brand of cigarettes. The company was so cager to have the President as their spokesm厉 they were even willing to allow Roosevelt fto write the endorsement himself. According to Bergin, Roosevelt responded by leter with a testimonial that stated he had $\cong$ smoked the company's cigarettes since the ase of 13 and had been coughing ever since. The company subsequently withdrew its offer. \&

Perhaps the biggest controversyegarding the smoking Roosevelt silhouette is the message that such a figure is giving to the youn ple, particularly adolescents, are extremely susceptible to images associated with tobacco use. ${ }^{4-6}$ Developmentally, adolescents are at a 


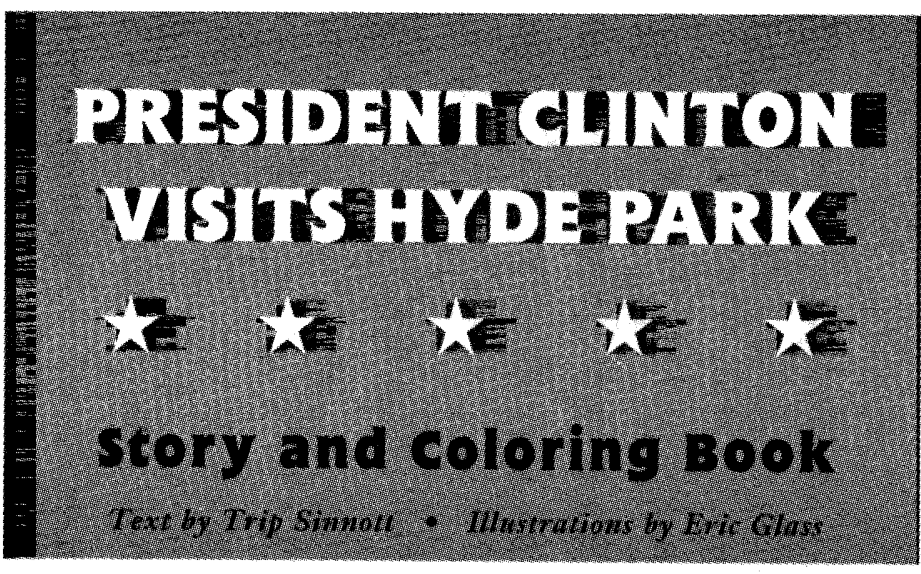

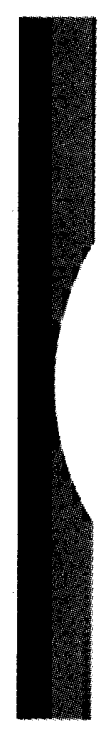
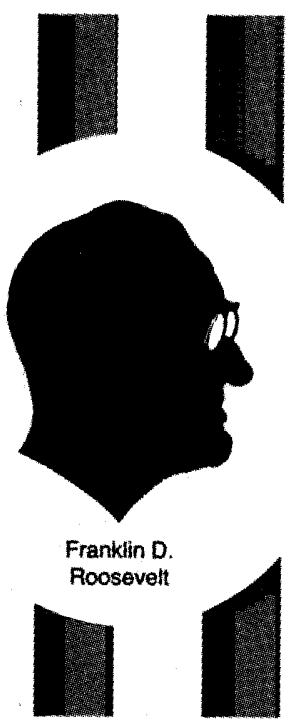
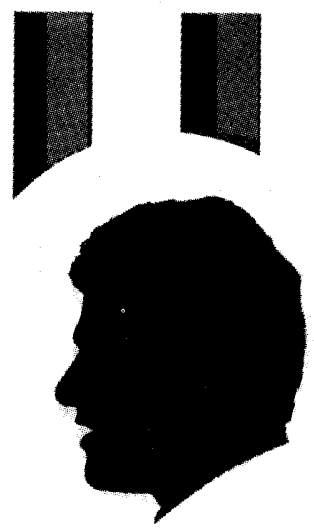

Bill

Clinton

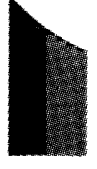

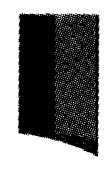

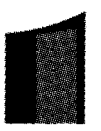

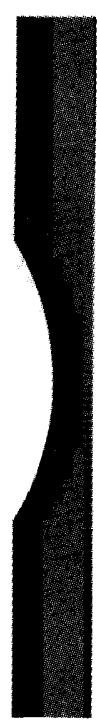

Figure 4 Cover of a colouring book sold in the gift shop in the FDR presidential library and museum, showing a silhouette of FDR without the cigarette.

stage where they are influenced by images and are driven by a need for peer acceptance. ${ }^{7}$ For these susceptible youth, a silhouette of FDR with a cigarette perpetuates the myth that smoking is socially acceptable. In addition, the silhouette associates smoking with FDR's success, prestige, and money-qualities that are extremely attractive to young people. ${ }^{4}$

Those who oppose the changing of Hyde Park's official town seal to the smoking silhouette of FDR are accused of being historical revisionists. Many people feel that FDR with a cigarette holder clenched in his teeth was a symbol of hope, optimism, and energy through the Depression era and World War II. To these people, excluding the cigarette is merely denying what this image meant to many during troubled times.

However, it begs the question that, if Roosevelt's smoking was something to be remembered, why is there not one picture of him smoking a cigarette or clenching his famous cigarette holder, in the many pictures on permanent display at the Roosevelt presidential library? There may be a similar explanation in the museum gift shop. Available among the souvenirs to commemorate President Roosevelt is a colouring book called President Clinton Visits Hyde Park. ${ }^{8}$ On the cover of this book (figure 4) are two silhouettes-one of President Clinton and the now famous silhouette of FDR without his cigarette. Wherp Trip Sinnott, author of the book, was asked about the exclusion of the cigarette from the front cover, he stated that an image of FDR. with a cigarette was not appropriate for the children who would be reading his books (August 1995).

The current debate regarding historical revi-흠 sionism may be similarly applied to the facts that FDR was a paraplegic after a bout with polio in August 1929. Despite this reality, Roo-w sevelt went to great lengths to conceal hisaffliction throughout his presidency. According; to Hugh Gregory Gallagher's book FDR's splendid deception, only two known pictures of Roosevelt in his wheelchair exist at the é presidential library. ${ }^{9}$ When standing or walkingt at public events, it was only with the aid of strong man on whom he could lean.

This affliction was just as much a part of Roosevelt as his cigarette smoking. Where Roosevelt's cigarette smoking may have been symbolic of hope and prosperity to people dur- $-\frac{\mathbb{}}{3}$ ing the Depression, perhaps a symbol of Roosevelt in a wheelchair could be similarly perceived by those who are disabled today. $\vec{\emptyset}$ Such a symbol would show the success thato could be achieved despite physical limitations and the fact that these limitations did not makes Roosevelt any less of a great leader. Would a⿳亠二口 request to honour the President in this wayo draw such accusations of changing history, $\Omega$ given the fact that FDR tried desperately to $\overrightarrow{0}$ hide his handicap, or would it merely be viewed 3 as an effort to perpetuate the symbol of hope, optimism, and prosperity with which FDR has? been associated in the past? Is the desire toot keep a cigarette in Roosevelt's mouth, despite opposition by the public health community, aم̂ fight to preserve history or to perpetuate the social acceptability of smoking, which has been on the decline in recent years?

In response to the concerns that have arisen since he proposed making the Roosevelt: silhouette the official town seal, Kevin Bergin has conducted an informal (convenience) survey of the image preferred by the town's residents. The survey presented four different $\frac{D}{O}$ figures: the official town seal with the family crests of the Roosevelt and Stoutenbourgh $N$ families, the silhouette of Roosevelt with then cigarette, a picture of Roosevelt without theN cigarette, and a picture of both Franklin and ${ }_{\sigma}^{\omega}$ Eleanor Roosevelt (figure 2). Some residents were in favour of adopting the FDR silhouette $\frac{\text { C }}{\Phi}$ as a new seal, but it seems for now that the? Hyde Park town council, who would ultimately decide on the seal, does not want to change from the present combination of family crests. $\stackrel{\mathbb{Q}}{\oplus}$

In the end, Hyde Park must choose between $\stackrel{\mathbb{8}}{\circ}$ a symbol of the past without regard to its present-day message, and an image that 0 honours the esteemed former President and응 has meaning for American society within the context of today's values. Efforts to remove the cigarette from FDR's mouth should not be viewed as revisionism but editorialismallowing contemporary America to decide on a 
symbol that is historically accurate and beneficial for future generations. Choosing an image of Franklin Delano Roosevelt without his cigarette does not change history; it merely emphasises the man and his contribution to the country without perpetually glorifying a deadly and addictive behaviour that was responsible for his early death.

1 Bruenn HG. Clinical notes on the illness and death of President Franklin D Roosevelt. Ann Intern Med 1970;72:57991.

2 Lutschg JH. Stamping out cigarettes. Tobacco Control 1994; 3:304-5.

3 US Department of Health, Education, and Welfare. Smoking and health. Report of the Advisory Committee to the Surgeon General of the Public Health Service. Washington, Surgeon General of the Public Health Service.

4 Davis RM. Current trends in cigarette advertising and marketing. $N$ Engl f Med 1987;316:715-32.

$5 \mathrm{La}$ Greca AM, Fisher EB. Adolescent smoking. Pediatr Ann 1992;21:241-4, 247-8.

6 US Department of Health and Human Services. Preventing tobacco use among young people. A report of the Surgeon Gen-
eral. Atlanta, Georgia: Public Health Service, Centers for eral. Atlanta, Georgia: Public Health Service, Centers for
Disease Control and Prevention, Office on Smoking and Disease Control and Prevention, Office on Smoking and
Health, 1994 (US Government Printing Office No S/N Health, 1994 (US

7 Erikson EH. Childhood and society. New York: WW Norton, 1950.

8 Sinnott T. President Clinton visits Hyde Park. Clinton Corners, New York: Attic Studio Press, 1993.
9 Gallagher HG. FDR's splendid deception. New York: Dodd, Mead, 1985.

Addendum Since the proposal to change the seal of Hyde Park in the summer of 1995, there has been no action by the town 产ouncil. The issue seems to have died and willaikely be forgotten now that all of the majo ${ }^{2}$ celebrations surrounding the end of World War II and the 50th anniversary of the death of FDR have passed. Kevin Bergin, the townin councilman who proposed the change in the $\vec{\theta}$ wn seal, did not seek re-election to his seat. His term on the council ended at the end of 199 There have been no other council members of̂citizens who have pursued the issue, and it is inot likely to re-surface anytime soon. Although the FDR silhouette with the cigaratte and holder can still be seen in various places in Hyde Park, it is not, and I hope will never become, the official town seal. In some small way, a victory the public health point of view has been wor

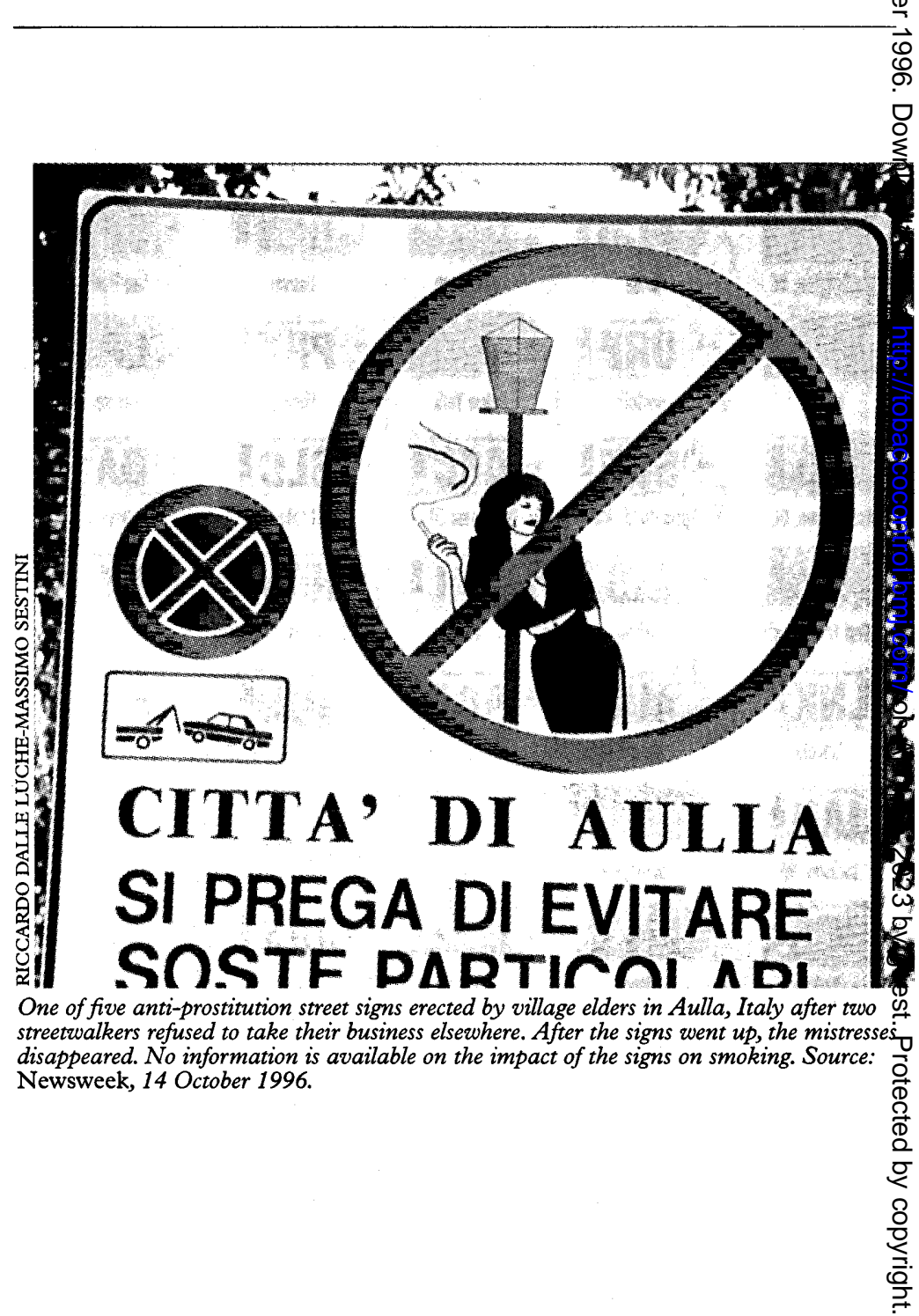

